\title{
THE EFFECT OF HOMO - AND HETERO - FERMENTATIVE LACTIC ACID BACTERIA MIX ON THE ENSILED LUCERNE FERMENTATION CHARACTERISTICS AND AEROBIC STABILITY IN BIG BALES
}

\begin{abstract}
Robertas STOŠKUS, Institute of Animal Science, Lithuanian University of Health Sciences, 12 R. Zebenkos, Baisogala, Radviliskis dist., LT-82317, Lithuania, robertas.stoskus@1smuni.lt (corresponding author)

Jonas JATKAUSKAS, Institute of Animal Science, Lithuanian University of Health Sciences, 12 R. Zebenkos, Baisogala, Radviliskis dist., LT-82317, Lithuania, jonas.jatkauskas@1smuni.lt

Vilma VROTNIAKIENE, Institute of Animal Science, Lithuanian University of Health Sciences, 12 R. Zebenkos, Baisogala, Radviliskis dist., LT-82317, Lithuania, vilma.vrotniakiene@1smuni.lt

Vida JUOZAITIENĖ, Department of Animal Breeding and Nutrition, Faculty of Animal Husbandry Technology, 18 Tilzes, Kaunas, Lithuania, vida.juozaitiene@1smuni.lt

The purpose of this study was to determine the effect of homo- and hetero-fermentative lactic acid bacteria mix on the ensiled lucerne fermentation characteristics and aerobic stability in big bales. The lucerne was ensiled without additives $(C)$ and treated with a mix of bacterial inoculant that contains Lactococcus lactis and Lactobacillus buchneri (50:50) (I). Silage was treated with bacterial inoculant, which significantly increased the total organic acids concentration by $69 \%$, lactic acid by $92 \%$ and acetic acid by $76 \%$. If the results were compared with the $\mathrm{C}$ silage, the inoculation significantly decreased the concentrations of butyric acid by $73 \%$, ethanol by $53 \%$ and ammonia - $\mathrm{N}$ concentration by $33 \%$. Inoculated silage had significantly lowered the yeast count by $59 \%$ and moulds count by $34 \%$. Compared to the inoculated silage and during the aerobic exposure, the untreated silage maximum temperature was significantly higher $\left(13.9^{\circ} \mathrm{C} v s 4.6^{\circ} \mathrm{C}\right)(\mathrm{P}$ $<0.05)$. Therefore, the bacterial inoculant improved the quality of fermentation and aerobic stability in lucerne silages.
\end{abstract}

Keywords: aerobic stability, lactic acid bacteria, lucerne, silage.

\section{INTRODUCTION}

Silage is one of the most important feed for cattles, and it is usually make up the largest part of the diet. The quality of the silage is one of the main factors that govern the health of cows and good quality products. (Baliukoniene et al., 2012). The available scientific data suggests that the quality of the silage is generally poor and it is, therefore, necessary to pay more attention to the quality of the feed.

The quality of the silages are affected by many factors, for example equipment and additives used during the ensiling process. The composition of the forage at ensiling as well as technique of silage preparation is important (Wyss and Latsch, 2015). It is known that monitoring of the silage making process can be a key factor in the silage fermentation, but even when controlling the process, the silage quality can vary greatly (Kasmaei et al., 2013).

After opening of the silo, yeast and moulds potentionaly can increase $\mathrm{pH}$ value and temperature of the silage as well as reduction of sugars. Loss of carbon dioxide and temperature increase cause dry matter losses and reduce the feeding value of silage (Muck, 2012). The homofermentative lactic acid bacteria (LAB) produces lactic acid and are most commonly used to preserve silage during storage, meanwhile, heterofermentative $\mathrm{LAB}$ produces lactic acid, $\mathrm{CO}_{2}$, ethanol as well as acetic acid which inhibits the growth of yeast and moulds (Milora et al., 2015).

Recently, inoculants containing homo- and hetero- fermanative LAB has become predominant additives, because the combination of both types of these LAB can reduce losses and increase the fermentation quality as well as aerobic stability of silage (Li et al., 2016). However, there is still a lack of information on the effects of Lactobacillus buchneri in combination with the Lactococcus lactis on the ensiled lucerne fermentation and the aerobic stability in big bales.

The purpose of this study was to determine the effect of homo- and hetero-fermentative lactic acid bacteria mix on the ensiled lucerne fermentation characteristics and aerobic stability in big bales.

\section{MATERIALS AND METHODS}

The experiment was held in 2016 at the Institute of Animal Science of Lithuanian University of Health Science. All materials and methods were made according to the DLG (Deutsche Landwirtschafts-Gesellschaft e. V. /internationally acknowledged German Agricultural Society), guidelines for the testing silage additives. 
The silages were made from the severely ensiled second growth cut lucerne that was wilted for 7-8 h. The Lucerne was harvested from one field and was baled into the $1.2 \mathrm{~m}$ wide and $1.2 \mathrm{~m}$ length cylindrical bales as well as wrapped with 6 layers of white coloured stretch pellicle (the width of $750 \mathrm{~mm}$ and the thickness of $0.025 \mathrm{~mm}$ ). We have prepared twenty big bales in total, ten with a mix of bacterial inoculant containing Lactococcus lactis and Lactobacillus buchneri (50:50) (I) and ten without any additives (C). The ammount of the inoculant, that was applied to the herbage, was 150 $000 \mathrm{cfu} \mathrm{g}^{-1}$ also adding $4 \mathrm{~L}$ suspension for 1 tonne of lucerne. Moreover the same amount $(4 \mathrm{~L} / \mathrm{t})$ of water was used instead of the suspension in the control treatment for the spontaneous fermentation. The blend of the bacterial strains was sprayed during the harvesting process while using the commercial sprayer HP-20. Samples of the water used for inoculation were collected and analyzed immediately (within an hour), using the ISO 15214 method. Both silages were kept in big bales for 120 days at outdoor temperature. Average of ambient temperature was $2.9^{\circ} \mathrm{C}$. Five representative samples (>500 g each) of harvested herbage were taken before the ensiling period. At the sampling time of silages on day 120 of the ensiling period, five replications per treatment (10 big bales) were weighed for determination of DM loss and subsequently opened and sampled to analyze the DM content, $\mathrm{pH}$, fermentation products and ammonia - N. The remaining 10 big bales ( 5 from each treatment) were used for the aerobic stability outdoor measurement. Aerobic stability was measured using data loggers that were placed in 5 controlling big bales and in 5 inoculated big bales to monitor temperature change inside the silage automatically every 6 hours, for up to 30 days (from day 120 to day 150 of storage). The aerobic deterioration was denoted by hours until the start of the sustained increase in temperature by more than $3^{\circ} \mathrm{C}$ above the ambient temperature.

Statistical analysis was determined using the SPSS program 20.0 for Windows. The results are presented as mean and standard deviation (mean $\pm \mathrm{SD}$ ) and $95 \%$ confidence interval for mean. The results were considered to be reliable under $\mathrm{P} \leq 0.05$.

\section{RESULTS}

The chemical and microbiological composition of fresh lucerne is summarized in Table 1. The lucerne was wilted up to $328 \mathrm{~g} \mathrm{~kg}^{-1}$ and had low WSC $\left(50.1 \mathrm{~g} \mathrm{~kg}^{-1} \mathrm{DM}\right)$ concentration while the concentrations of crude protein $\left(220.2 \mathrm{~g} \mathrm{~kg}^{-}\right.$ $\left.{ }^{1} \mathrm{DM}\right)$ and buffering capacity (48.9 $\mathrm{mEq} 100 \mathrm{~g} \mathrm{DM}^{-1}$ ) were high. Consequently, lucerne was difficult to ferment.

Table 1. Chemical and microbiological composition of a fresh lucerne at ensiling

\begin{tabular}{|c|c|c|c|}
\hline Variable & $\mathrm{n}$ & mean & SD \\
\hline Dry matter $\mathrm{g} \mathrm{kg}^{-1}$ & 5 & 327.6 & 4.74 \\
\hline Crude protein $\mathrm{g} \mathrm{kg}^{-1} \mathrm{DM}$ & 5 & 220.2 & 8.53 \\
\hline Crude fat $\mathrm{g} \mathrm{kg}^{-1} \mathrm{DM}$ & 5 & 18.8 & 2.39 \\
\hline Crude fibre $\mathrm{g} \mathrm{kg}^{-1} \mathrm{DM}$ & 5 & 293.6 & 19.45 \\
\hline Crude ash $\mathrm{g} \mathrm{kg}^{-1} \mathrm{DM}$ & 5 & 75.2 & 2.20 \\
\hline WSC g kg-1 DM & 5 & 50.14 & 2.11 \\
\hline NDF g kg${ }^{-1} \mathrm{DM}$ & 5 & 431.2 & 6.35 \\
\hline $\mathrm{ADF} \mathrm{g} \mathrm{kg}^{-1} \mathrm{DM}$ & 5 & 331.1 & 7.76 \\
\hline Yeast $\log _{10} \mathrm{cfu} \mathrm{g}^{-1}$ & 5 & 4.83 & 0.52 \\
\hline Moulds $\log _{10} \mathrm{cfu} \mathrm{g}^{-1}$ & 5 & 4.65 & 0.33 \\
\hline LAB $\log _{10} \mathrm{cfu} \mathrm{g}^{-1}$ & 5 & 4.92 & 0.07 \\
\hline Buffer capacity mEq $100 \mathrm{~g} \mathrm{DM}^{-1}$ & 5 & 48.9 & 6.63 \\
\hline $\mathrm{pH}$ & 5 & 6.17 & 0.02 \\
\hline
\end{tabular}

Note. DM - dry matter, WSC - water-soluble carbohydrate, ADF - acid detergent fibre, NDF - neutral detergent fibre, LAB - lactic acid bacteria, cfu - colony forming units, SD - standart deviation.

The results of chemical and microbiological analyses of the silages after 120 days of ensiling are submitted in Table 2. Application of the bacterial inoculant resulted in a higher dry matter content by $3.1 \%(\mathrm{P}<0.001)$ and less crude fiber content by $4.4 \%(\mathrm{P}<0.01)$. We have noticed that the inoculant treatment reduced DM losses by $44 \%(\mathrm{P}<0.001)$. Compared to the untreated silage, the inoculant treatment significantly increased the total organic acids concentration by $69 \%(\mathrm{P}<0.001)$, more lactic acid by $92 \%(\mathrm{P}<0.001)$, as well as much higher levels of acetic acid by $76 \%(\mathrm{P}<0.001)$. Compared to $\mathrm{C}$, the inoculation significantly decreased the concentrations of undesirable fermentation products such as butyric acid by $73 \%(\mathrm{P}<0.001)$ and ethanol by $53 \%(\mathrm{P}<0.001)$. Compared to the $\mathrm{C}$, the treatment with the bacterial mix reduced proteolysis of plant proteins, because ammonia $-\mathrm{N}$ concentration was lowered by $33 \%(\mathrm{P}<0.001)$ in the inoculated silage. The inoculant treatment increased the fermentation rate with a significantly deeper $\mathrm{pH}$ value by 0.34 units $(\mathrm{P}<0.001)$. Inoculated silage had significantly $(\mathrm{P}<0.001)$ lower yeast $(1.18$ vs 2.88$)$ and moulds $(1.42$ vs 2.15$)$ count and higher LAB count $(7.44$ vs 6.12$)(\mathrm{P}<0.001)$ compared to control silage.

The results of aerobic stability measurements of the silages are presented in Figure 1. Inoculated silage had significantly lower sum of mean temperature $\left(209.0{ }^{\circ} \mathrm{C}\right.$ vs $\left.390.4{ }^{\circ} \mathrm{C}\right)(\mathrm{P}<0.05)$ as well as maximum sample temperature compared to control silage $\left(4.6{ }^{\circ} \mathrm{C}\right.$ vs $\left.13.9{ }^{\circ} \mathrm{C}\right)(\mathrm{P}<0.05)$. 
Table 2. Chemical and microbiological composition of the silages after 120 days of storage

\begin{tabular}{|c|c|c|c|}
\hline Variable & $\mathrm{n}$ & $\mathrm{C}$ & I \\
\hline $\begin{array}{l}\text { Dry matter, corrected for volatiles } \mathrm{g} \mathrm{kg}^{-1} \\
\text { Lower Bound - Upper Bound } \\
\text { Mean } \pm \text { SD }\end{array}$ & 5 & $\begin{array}{c}308.14-316.26 \\
312.22 \pm 3.29 \\
\end{array}$ & $\begin{array}{c}320.04-323.96 \\
321.94 \pm 1.72 * * \\
\end{array}$ \\
\hline $\begin{array}{l}\text { DM losses } \mathrm{g} \mathrm{kg}^{-1} \mathrm{DM} \\
\text { Lower Bound - Upper Bound } \\
\text { Mean } \pm \mathrm{SD}\end{array}$ & 5 & $\begin{array}{c}92,41-100,53 \\
96.5 \pm 4.62\end{array}$ & $\begin{array}{l}50,25-58,38 \\
54.3 \pm 3.11^{* *}\end{array}$ \\
\hline $\begin{array}{l}\text { Crude protein } \mathrm{g} \mathrm{kg}^{-1} \mathrm{DM} \\
\text { Lower Bound - Upper Bound } \\
\text { Mean } \pm \mathrm{SD}\end{array}$ & 5 & $\begin{array}{c}209,69-216,53 \\
213.1 \pm 2.25\end{array}$ & $\begin{array}{c}213,89-220,73 \\
217.3 \pm 4.11\end{array}$ \\
\hline $\begin{array}{l}\text { Crude fibre } \mathrm{g} \mathrm{kg}^{-1} \mathrm{DM} \\
\text { Lower Bound - Upper Bound } \\
\text { Mean } \pm \text { SD }\end{array}$ & 5 & $\begin{array}{c}304.42-315.18 \\
309.8 \pm 5.71 \\
\end{array}$ & $\begin{array}{c}290.88-301.64 \\
296.3 \pm 4.67 * \\
\end{array}$ \\
\hline $\begin{array}{l}\text { WSC g kg-1 DM } \\
\text { Lower Bound - Upper Bound } \\
\text { Mean } \pm \text { SD }\end{array}$ & 5 & $\begin{array}{l}5.79-9.72 \\
7.75 \pm 2.52\end{array}$ & $\begin{array}{c}5.79-9.73 \\
7.76 \pm 1.18\end{array}$ \\
\hline $\begin{array}{l}\text { NDF } \mathrm{g} \mathrm{kg}^{-1} \mathrm{DM} \\
\text { Lower Bound - Upper Bound } \\
\text { Mean } \pm \text { SD }\end{array}$ & 5 & $\begin{array}{c}445.57-471.4 \\
458.5 \pm 17.91 \\
\end{array}$ & $\begin{array}{c}440.12-465.94 \\
453.0 \pm 12.87\end{array}$ \\
\hline $\begin{array}{l}\text { ADF } \mathrm{g} \mathrm{kg}^{-1} \mathrm{DM} \\
\text { Lower Bound - Upper Bound } \\
\text { Mean } \pm \text { SD } \\
\end{array}$ & 5 & $\begin{array}{c}362.29-386.73 \\
374.5 \pm 15.78 \\
\end{array}$ & $\begin{array}{c}356.2-380.65 \\
368.4 \pm 12.77 \\
\end{array}$ \\
\hline $\begin{array}{l}\text { Total acids } \mathrm{g} \mathrm{kg}^{-1} \mathrm{DM} \\
\text { Lower Bound - Upper Bound } \\
\text { Mean } \pm \mathrm{SD}\end{array}$ & 5 & $\begin{array}{c}49,36-59,04 \\
54.2 \pm 3.90\end{array}$ & $\begin{array}{l}84,43-99,17 \\
91.8 \pm 5.93 * *\end{array}$ \\
\hline $\begin{array}{l}\text { Lactic acid } \mathrm{g} \mathrm{kg}^{-1} \mathrm{DM} \\
\text { Lower Bound - Upper Bound } \\
\text { Mean } \pm \mathrm{SD}\end{array}$ & 5 & $\begin{array}{c}27.19-36.81 \\
32.0 \pm 3.87\end{array}$ & $\begin{array}{l}55.47-67.33 \\
61.4 \pm 4.78^{* *}\end{array}$ \\
\hline $\begin{array}{l}\text { Acetic acid } \mathrm{g} \mathrm{kg}^{-1} \mathrm{DM} \\
\text { Lower Bound - Upper Bound } \\
\text { Mean } \pm \mathrm{SD}\end{array}$ & 5 & $\begin{array}{c}14.18-17.42 \\
15.8 \pm 1.30\end{array}$ & $\begin{array}{l}26.18-29.42 \\
27.8 \pm 1.30 * *\end{array}$ \\
\hline $\begin{array}{l}\text { Butyric acid } \mathrm{g} \mathrm{kg}^{-1} \mathrm{DM} \\
\text { Lower Bound - Upper Bound } \\
\text { Mean } \pm \mathrm{SD}\end{array}$ & 5 & $\begin{array}{l}4.89-6.07 \\
5.49 \pm 0.68\end{array}$ & $\begin{array}{c}0.91-2.09 \\
1.50 \pm 0.43 * *\end{array}$ \\
\hline $\begin{array}{l}\text { Propionic acid } \mathrm{g} \mathrm{kg}^{-1} \mathrm{DM} \\
\text { Lower Bound }- \text { Upper Bound } \\
\text { Mean } \pm \mathrm{SD}\end{array}$ & 5 & $\begin{array}{l}0.47-0.88 \\
0.67 \pm 0.21\end{array}$ & $\begin{array}{l}0.75-1.16 \\
0.96 \pm 0.19\end{array}$ \\
\hline $\begin{array}{l}\text { Ethanol } \mathrm{g} \mathrm{kg}^{-1} \mathrm{DM} \\
95 \% \text { Confidence Interval for mean } \\
\text { Lower Bound - Upper Bound } \\
\text { Mean } \pm \text { SD }\end{array}$ & 5 & $\begin{array}{c}6.76-9.24 \\
8.0 \pm 1.0\end{array}$ & $\begin{array}{c}3.16-5.24 \\
4.2 \pm 0.84^{* *}\end{array}$ \\
\hline $\begin{array}{l}\text { Ammonia } \mathrm{N} \mathrm{g} \mathrm{kg}^{-1} \text { total } \mathrm{N} \\
\text { Lower Bound }- \text { Upper Bound } \\
\text { Mean } \pm \mathrm{SD}\end{array}$ & 5 & $\begin{array}{c}39.2-45.63 \\
42.4 \pm 3.87\end{array}$ & $\begin{array}{l}25.41-31.83 \\
28.6 \pm 2.11^{* *}\end{array}$ \\
\hline $\begin{array}{l}\text { Yeast } \log _{10} \mathrm{cfu}^{-1} \\
\text { Lower Bound - Upper Bound } \\
\text { Mean } \pm \text { SD }\end{array}$ & 5 & $\begin{array}{l}2.55-3.22 \\
2.88 \pm 0.12\end{array}$ & $\begin{array}{c}0.85-1.52 \\
1.18 \pm 0.27^{* *}\end{array}$ \\
\hline $\begin{array}{l}\text { Moulds } \log _{10} \mathrm{cfu} \mathrm{g}^{-1} \\
\text { Lower Bound - Upper Bound } \\
\text { Mean } \pm \text { SD }\end{array}$ & 5 & $\begin{array}{l}1.93-2.38 \\
2.15 \pm 0.15\end{array}$ & $\begin{array}{l}1.19-1.65 \\
1.42 \pm 0.16^{* *}\end{array}$ \\
\hline $\begin{array}{l}\text { LAB } \log _{10} \mathrm{cfu}^{-1} \\
\text { Lower Bound - Upper Bound } \\
\text { Mean } \pm \text { SD }\end{array}$ & 5 & $\begin{array}{c}5.91-6.32 \\
6.12 \pm 0.18 \\
\end{array}$ & $\begin{array}{c}7.23-7.64 \\
7.44 \pm 0.31 * *\end{array}$ \\
\hline $\begin{array}{l}\text { Lower Bound - Upper Bound } \\
\text { Mean } \pm \text { SD }\end{array}$ & 5 & $\begin{array}{l}4.75-4.83 \\
4.79 \pm 0.06\end{array}$ & $\begin{array}{c}4.4-4.49 \\
4.45 \pm 0.05^{* *}\end{array}$ \\
\hline
\end{tabular}

Note. DM - dry matter, WSC - water-soluble carbohydrate, ADF - acid detergent fibre, NDF - neutral detergent fibre, cfu - colony forming units, SD - standart deviation.

$*$ and $* *$ denote statistically significant difference vs control at level 0.01 and 0.001 , respectively. 


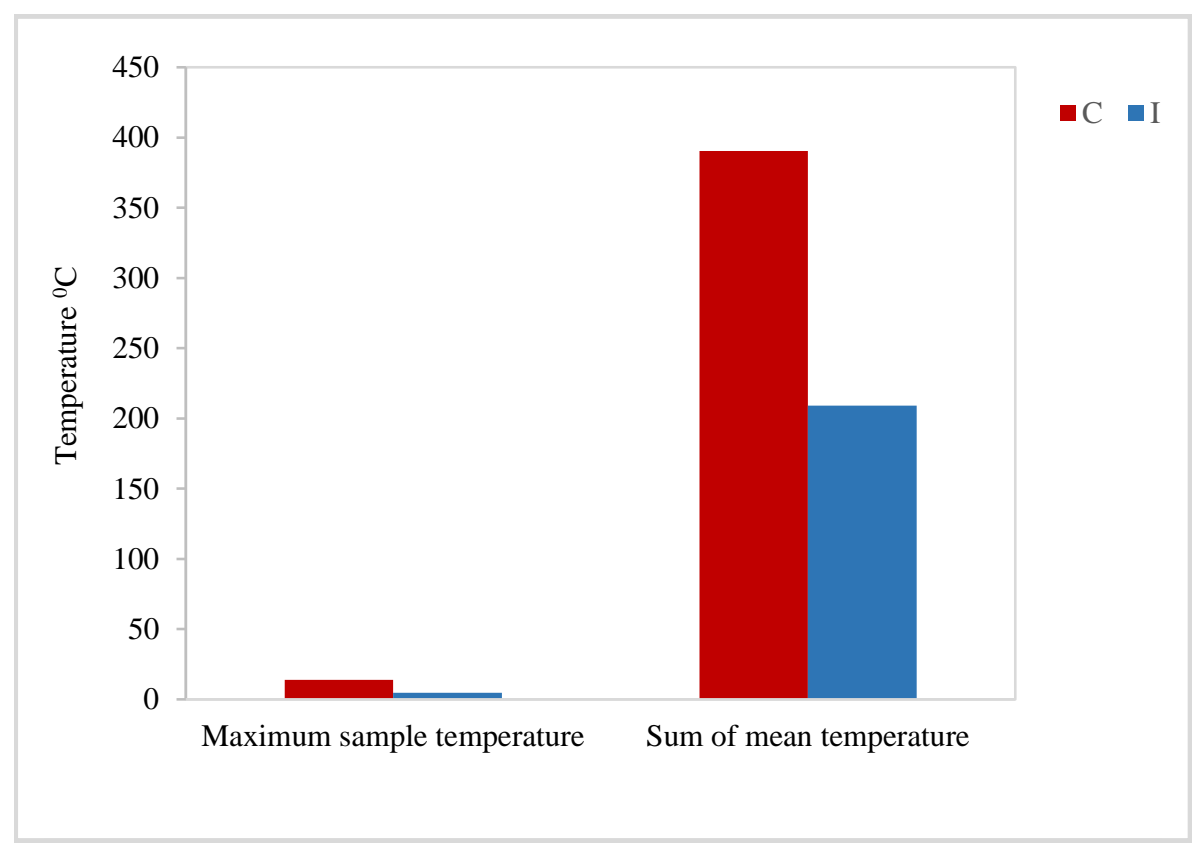

Figure 1. Aerobic stability measurements

\section{DISCUSSION}

Our findings showing that $\mathrm{LAB}$ inoculation of lucerne improved silage fermentation by increasing lactic acid and reducing $\mathrm{pH}$ value. The obtained results meet the results provided by Hindrichsen et al., (2012), where L. lactis was superior in removing oxygen, $\mathrm{pH}$ reduction and clostridia inhibition. The lower ammonia - $\mathrm{N}$ concentration in the inoculated silage suggests that the inoculant reduced poteolysis. These results confirm the researches received earlier by Vrotniakiene and Jatkauskas, 2014. The inoculant has substantially reduced the levels of unwanted fermentation products, for example ethanol and butyric acid concentrations. The data obtained by the latter, confirm the data of other researchers in which the heterofermentative LAB was used alone or together with homofermentative LAB (Schmidt and Kung, 2010).

We have noticed that the addition of bacterial inoculant resulted higher level of acetic acid. It is well known that L. buchneri produce acetic acid, which inhibits growth of yeast and moulds and as the result can increase aerobic stability of silages (Jatkaukas and Vrotniakienè, 2012). The present study demonstrated that the inoculated silage had significantly lower yeast and moulds count compared to the control silage. The addition of he + ho LAB effectively inhibited the growth of yeast in the silage ( $\mathrm{Li}$ et al., 2016).

The use of silage inoculants based on hetero- and homo- fermentative LAB, has been used relatively recently, but according to recent researches, these bacteria have a positive effect on aerobic stability of silages (Kung et al., 2003; Kang et al., 2009; Wambacq et al., 2013).

\section{CONCLUSIONS}

Addition of the bacterial inoculant containing of Lactococcus lactis and Lactobacillus buchneri in lucerne:

a) gave the better fermentation, lower $\mathrm{pH}$ and accelerates the lactic acid and acetic acid formation;

b) decreased of the concentration of undesirable fermentation products such as butyric acid and ethanol and significantly reduced the DM loss;

c) reduced ammonia $-\mathrm{N}$ concentration and was effective in limiting the degradation of protein;

d) improved the hygienic quality of the lucerne silage by lowering growth of moulds, which are able to produce potent mycotoxins that are harmful to animals and humans, and enhances silage aerobic stability.

\section{REFERENCES}

1. Baliukonienè, V., Bakutis, B., Vaivadaitė, T., Bartkienė, E., Jovaišienė, J. 2012. Prevalence of fungi and mycotoxins in silage and milk in Lithuania. Veterinarija ir zootechnika, Vol. 59, Iss 81, pp. 3-9.

2. Hindrichsen, I.K., Augustsson, E.U., Lund, B., Jensen, M.M., Raun, M., Jatkauskas, J., Vrotniakienė, V., Ohlsson, C. 2012. Characterisation of different lactic acid bacteria in terms of their oxygen consuming capacity, aerobic stability and pathogen inhibition. Proceedings of the "16th International Silage Conference", Book 1, pp. 105-106, Hameenlinna, Finland.

3. ISO 15214 "Horizontal method for the enumeration of mesophilic lactic acid bacteria - Colony-count technique". Available at https://www.iso.org/obp/ui/\#iso:std:iso:15214:ed-1:v1:en (accessed on 30/11/2017) 
4. Jatkauskas, J., Vrotniakiene, V., Ohlsson, C., Lund, B. 2012. The effects of three silage inoculants on aerobic stability in grass, clover-grass, lucerne and maize silages. Proceedings of the "16th International Silage Conference", Book 1, pp. 404-405, Hameenlinna, Finland.

5. Kang, T.W., Adesogan, A.T., Kim, S.C., Lee, S.S. 2009. Effects of an esterase-producing inoculant on fermentation, aerobic stability, and neutral detergent fiber digestibility of corn silage. Journal of dairy science. Vol. 92, Iss 2, pp. $732-738$. https://doi.org/10.3168/jds.2007-0780

6. Kasmaei, K. M., Rustas, B. O., Spörndly, R., Udén, P. 2013. Prediction models of silage fermentation products on crop composition under strict anaerobic conditions: A meta-analysis. Journal of dairy science, Vol. 96, Iss 10, pp. 6644-6649. https://doi.org/10.3168/jds.2013-6858

7. Kung, L., Taylor, C.C., Lynch, M.P., Neylon, J.M. 2003. The effect of treating alfalfa with Lactobacillus buchneri 40788 on silage fermentation, aerobic stability, and nutritive value for dairy cows. Journal of dairy science, Vol. 86, Iss 1, pp. 336-343. https://doi.org/10.3168/jds.S0022-0302(03)73611-X

8. Kung, L., Taylor, C. C., Lynch, M. P., Neylon, J. M. 2003. The effect of treating alfalfa with Lactobacillus buchneri 40788 on silage fermentation, aerobic stability, and nutritive value for lactating dairy cows. Journal of dairy science, Vol. 86 Iss 1 , pp. 336-343. https://doi.org/10.3168/jds.S00 22-0302(03)73611-X

9. Li, X., Xu, W., Yang, J., Zhao, H., Pan, C., Ding, X., Zhang, Y. 2016. Effects of applying lactic acid bacteria to the fermentation on a mixture of corn steep liquor and air-dried rice straw. Animal Nutrition, Vol. 2, Iss 3, pp. $229-233$. https://doi.org/10.1016/j.aninu.2016.04.003

10. Milora, N., Hindrichsen, I. K., Richelieu, M., Geppel, A. 2015. Developing a novel dual purpose silage inoculant. Proceedings of the "17th International Silage Conference", pp. 352-353. Piracicaba, Brazil.

11. Muck, R. Microbiology of ensiling. 2012. Proceedings of the "16th International Silage Conference", Book 1, pp. 75-86, Hameenlinna, Finland.

12. Schmidt, R. J., Kung, L. 2010. The effects of Lactobacillus buchneri with or without a homolactic bacterium on the fermentation and aerobic stability of corn silages made at different locations. Journal of dairy science, Vol. 93, Iss 4, pp. 1616-1624. https://doi.org/10.3168/jds.2009-2555

13. Vrotniakienė, V., Jatkauskas, J. 2014. Improved production of big bale lucerne silage using lactic acid bacteria blend inoculant Proceedings of the „16th International Symposium of Forage Conservation“, pp. 149-150. Mendel University at Brno, Czech Republic.

14. Wambacq, E., Latré, J. P., Haesaert, G. 2013. The effect of Lactobacillus buchneri inoculation on the aerobic stability and fermentation characteristics of alfalfa-ryegrass, red clover and maize silage. Agricultural and Food Science, Vol. 22, Iss 1, pp. 127-136.

15. Wyss, U., Latsch, A. 2015. Influence of different slurry application methods on grass silage quality. Proceedings of the „17th International Silage Conference“, pp. 180-181. Piracicaba, Brazil. 